\title{
PELATIHAN PENGEMBANGAN PENILAIAN KINERJA MENULIS BAHASA INGGRIS BAGI GURU BAHASA INGGRIS SMA KECAMATAN BULELENG
}

\author{
oleh, \\ A.A.I.N. Marhaeni \\ Jurusan Pendidikan Bahasa Inggris \\ Fakultas Bahasa dan Seni \\ Universitas Pendidikan Ganesha
}

\begin{abstract}
ABSTRAK
Kegiatan pengabdian kepada masyarakat dalam bentuk workshop berkelanjutan ini dilaksanakan berdasarkan hasil penelitian yang dilaksanakan oleh Prof. Dr. A.A. Istri Ngurah Marhaeni, M.A (2009). Ada tiga tahap pelaksanaan kegiatan: pelatihan, implementasi, dan refleksi serat perencanaan tindak lanjut.bSecara umum, pelaksanaan P2M berjalan dengan baik, semua peserta: 17 orang guru Bahasa Inggris SMA dan 3 pengawas mata pelajaran Bahasa Inggris SMA Kecamatan Buleleng, hadir dalam setiap tahapan kegiatan. Guru-guru mampu mengimplemenasikan instrument penilaian kinerja menulis dengan baik pula. Instrument tersebut dapat membantu guru untuk lebih objektif untuk memberikan penilaian terhadap kemampuan menulis siswa; melatih siswa untuk bisa menjadi pebelajar mandiri, lebih teliti karena berpatokan pada instrument yang sangat rinci sehingga mereka mampu mengevaluasi dirinya sendiri; dan adanya pemantauan dalam proses menulis membantu siswa untuk menghasilkan karya yang lebih baik. Namun, disisi lain, pengimplementasian instrument ini juga memiliki kelemahan. Instrumen yang rinci (analitik) terkesan rumit untuk diimplementasikan oleh beberapa orang guru pada awalnya sehingga perlu waktu yang lebih banyak untuk melakukan penskoran. Karena instrument ini digunakan juga untuk menilai proses, maka jumlah pertemuan pun jadi bertambah sedangkan keterampilan berbahasa yang lain juga harus diajarkan, dan input siswa yang rendah juga mempengaruhi kesuksesan penimplementasian instrument. Jadi disarankan, dengan kondisi sekolah yang berbeda-beda, terutama dari input siswa, guru agar tetap termotivasi untuk berlatih mengimplementasikan instrument tersebut agar dapat mendorong siswa untuk berprestasi. Instrumen tersebut bisa menjadi jalan keluar untuk bisa melatih diri menjadi objektif, melatih siswa untuk sadar akan dikelemahan dan kelebihan yang dimilikinya dalam menulis, serta mampu menghargai suatu proses dari pada hanya sekadar hasil.
\end{abstract}

Kata-kata kunci: penilaian kinerja, menulis, bahasa inggris

\section{Pendahuluan}

Kurikulum berbasis kompetensi yang dianut oleh sistem pendidikan kita dewasa ini menuntut kesiapan berbagai pihak, terutama guru sebagai ujung tombak pelaksanaan pembelajaran di sekolah. Orientasi terhadap pembentukan kompetensi pada siswa 
merujuk pada pentingnya pembelajaran yang bermakna, yaitu bahwa, pembelajaran tersebut benar-benar mengantarkan siswa pada aktivitas-aktivitas penyelesaian masalah nyata sehingga dapat dia gunakan untuk mencapai kehidupan yang lebih baik. Mochtar Buchori (2005) menekankan bahwa pendidikan yang bermakna akan menolong anak, sedangkan pendidikan yang tidak bermakna hanya akan menjadi beban bagi anak. Dengan demikian, pendidikan melalui pembelajaran yang bermakna sangat patut untuk diperjuangkan.

Pembelajaran yang bermakna harus kontekstual. Berbicara mengenai pembelajaran kontekstual bukanlah berbicara mengenai suatu metode atau teknik pembelajaran, melainkan mengenai suatu filosofi atau pendekatan tentang bagaimana semestinya pembelajaran yang bermakna itu terjadi. Hingga saat ini, para guru telah banyak mendapat pendidikan maupun pelatihan tentang melaksanakan pembelajaran secara kontekstual, sehingga, baik secara kuantitatif maupun kualitatif kompetensi profesional guru sudah meningkat. Peningkatan itu terlihat dari kemampuan merancang pembelajaran dan melaksanakan pembelajaran secara inovatif.

Namun demikian, analisis kebutuhan dalam rangka penelitian pengembangan instrument yang dilakukan oleh Marhaeni (2009) menemukan bahwa guru bahasa Inggris SMA di Singaraja pada umumnya masih belum mampu menyusun instrumen penilaian yang berorientasi kinerja. Pada umumnya, guru-guru tersebut menilai unjuk kerja berbahasa siswa melalui pengamatan dengan hamper-hampir tidak menggunakan instrument. Sebagai contoh, untuk menilai kemampuan bercerita (story telling), guru tidak menetapkan aspek-aspek kemampuan apasaja yang akan dinilai. Guru tergantung pada professional judgment nya (yang lebih condong berupa personal judgment, alias kesan yang muncul selama siswa berunjukkerja). Alhasil, terjadi ke tidak-taat-asas-an praktik penilaian, karena sangat mungkin terjadi rendahnya konsistensi penilaian, pengabaian konstruk pembangun kemampuan tertentu karena hanya berdasarkan impresi guru (bukan penguasaan guru terhadap konstruk kemampuan yang dinilai). Untuk itu, merespon tuntutan orientasi kurikulum yang berbasis kompetensi, guru perlu dibantu untuk dapat menerapkan strategi asesmen yang sesuai. Agar sistem dan model penilaian di lapangan menjadi tepat azas dan tepat sasaran sesuai dengan esensi KTSP, 
maka guru Bahasa Inggris SMA di Singaraja perlu dibantu untuk mengembangkan perangkat asesmen yang sesuai.

Penelitian yang dilakukan oleh Marhaeni dkk. (2010; 2009) tentang pengembangan instrument penilaian kinerja menulis bahasa Inggris SMA telah menghasilkan seperangkat instrumen yang terdiri dari rubrik penilaian kemampuan menulis bahasa Inggris, ceklis pemantauan peningkatan kemampuan menulis, dan kuesioner tentang konsep diri dan motivasi berprestasi dalam belajar bahasa Inggris yang berorientasi pada aspek budaya Bali, yaitu konsep ede ngaden awak bise (konsep diri) dan jengah (motivasi berprestasi). Melihat bahwa guru-guru bahasa Inggris SMA di Kecamatan Buleleng belum memiliki kompetensi yang memadai dalam melakukan asesmen berbasis kompetensi, serta telah adanya penelitian yang mengembangkan instrumen termaksud dan telah sesuai dengan kebutuhan lapangan, maka sangat perlu dilakukan diseminasi hasil penelitian tersebut dalam bentuk pengabdian kepada masyarakat (P2M) bagi guru-guru bahasa Inggris SMA.

P2M ini memiliki arti penting, pertama, adanya suatu usaha untuk mendiseminasikan hasil penelitian dalam kancah masyarakat yang relevan, yaitu guru bahasa Inggris SMA, kedua adanya manfaat yang diperoleh guru, yaitu kemampuan menyelenggarakan penilaian yang taat asas, ketiga, secara lebih luas P2M ini adalah menjembatani antara theory and practice sehingga benar-benar hasil penelitian dapat disumbangkan untuk kemaslahatan hidup masyarakat.

Yang menjadi sasaran P2M ini adalah guru-guru bahasa Inggris SMA yang tergabung dalam MGMP Bahasa Inggris SMA, dengan anggota berjumlah 26 orang guru (data dari Ketua MGMP Bahasa Inggris SMA Kabupaten Buleleng). Mengingat pembelajaran bahasa Inggris di SMA khususnya di kecamatan Buleleng sudah cukup inovatif dimana banyak dilakukan penugasan seperti conversation, story telling, debate, maupun menulis secara transaksional maupun interpersonal namun cara penilaian kinerja ini belum memadai dan belum taat asas, maka mereka ini yang akan dijadikan sasaran P2M. Adanya kesiapan MGMP Bahasa Inggris SMA se kecamatan Buleleng untuk terlibat dalam P2M ini merupakan potensi yang sangat mendukung pelaksanaan P2M. Seperti diketahui bahwa MGMP kecamatan Buleleng secara rutin melakukan pertemuan, maka kesempatan ini akan digunakan untuk melakukan pelatihan. 
Pendidikan adalah proses pemenusiaan manusia, maka dari itu dalam tataran yang lebih operasioanal dapat dikatakan bahwa tuntutan pendidikan adalah terbentuknya kompetensi pada peserta didik (terlepas dari apakah kurikulum yang sekarang tetap digunakan atau diganti, tetapi pembentukan kompetensi adalah merupakan suatu keharusan). Untuk itu, perlu dilakukan pembenahan dalam praktik pembelajaran di sekolah, termasuk praktek asesmennya. Asesmen berbasis kompetensi merupakan asesmen yang dilakukan untuk mengetahui kompetensi seseorang. Kompetensi adalah atribut individu peserta didik, oleh karena itu asesmen berbasis kompetensi bersifat individual; sehingga ia disebut asesmen berbasis kelas. Untuk memastikan bahwa yang diases tersebut benar-benar adalah kompetensi riil individu (peserta didik) tersebut, maka asesmen harus dilakukan secara otentik (nyata, riil seperti kehidupan sehari-hari). Asesmen otentik bersifat on-going atau berkelanjutan, oleh karena itu asesmen harus dilakukan kepada proses dan produk belajar. Dengan demikian, asesmen berbasis kompetensi memiliki sifat otentik, berkelanjutan, dan individual. Sifat-sifat asesmen berbasis kompetensi tersebut mengindikasikan bahwa jenis tes objektif (seperti tes pilihan ganda, benar-salah, dan lain-lain) yang dimasa lalu mendominasi penilaian di sekolah tidak lagi relevan saat ini. Sudah saatnya (dan secepat mungkin) proses pembelajaran ditopang secara kukuh dengan penggunaan asesmen otentik seperti asesmen kinerja, evaluasi diri, esai, asesmen portofolio, dan projek.

Menulis adalah suatu serial aktivitas yang berulang-ulang dalam menuangkan pikiran dalam tulisan (o'Donnel dan Paiva, 1993). Keterampilan menulis merupakan salahsatu keterampilan berbahasa yang sangat penting, terutamanya ketika belajar di perguruan tinggi. Namun, studi yang dilakukan oleh Brocato dkk. (2006) menunjukkan kurangnya kemampuan siswa dalam hal ini. Sejalan dengan hal ini, penelitian yang dilakukan oleh pemerintah Norwegia yang dilakukan secara nasional mengenai caracara apa saja yang digunakan guru bahasa Inggris dalam mengajar keterampilan menulis (Fasting, dkk 2009), menemukan praktik pembelajaran yang tidak tepat azas sehingga tidak terjadi pembelajaran yang efektif.

Proses menulis adalah suatu kegiatan kognitif. Sebagai suatu proses kognitif, menulis adalah suatu alat yang digunakan untuk menuangkan buah pikiran. Menurut Vygotsky dalam bukunya "Thought and Language" (Confrey, 1995), pikiran dan bahasa 
pada awalnya berasal dari akar yang berbeda. Ujaran (speech) yang merupakan dasar pengembangan kemampuan berbahasa berkembang dari isyarat-isyarat dan responrespon afektif yang terjadi dalam konteks komunikasi dan interaksi sosial; sedangkan pikiran terutama logika berpikir, berkembang dari aktivitas, yaitu pengalaman dengan diri dan lingkungan. Dialektika bahasa dan pikiran ini, walaupun berasal dari akar yang berbeda, pada akhirnya menyatu dalam memfasilitasi perkembangan konsep-konsep. Menurut Piaget, terdapat suatu skema dalam pikiran yang mengatur interaksi manusia dengan lingkungannya. Skema adalah susunan sekumpulan informasi tentang pengetahuan dan pengalaman. Skema adalah layaknya sebagai suatu reservoir di dalam pikiran yang berisi berbagai perolehan informasi yang tersimpan dalam pikiran tersebut.

Namun, Vygotsky (Solso, dkk; 2005) mengatakan bahwa pikiran (mind) pada hakikatnya bersifat sosial. Ia menekankan pentingnya faktor mediasi dalam perolehan pengetahuan. Lingkungan, baik lingkungan sosial maupun budaya yang berperan sebagai mediator, besar pengaruhnya dalam pembentukan pengalaman belajar. Intervensi yang efektif sangat penting untuk pengembangan kemampuan kognitif. Struktur kognitif merupakan produk interaksi dua modalitas yaitu: (1) ekspose langsung organisme terhadap pengalaman, dalam bentuk stimulus - organism - response (SOR) yang merupakan model pengembangan kognitif dari Piaget, dan (2) interaksi organisme dengan lingkungan melalui mediator kemanusiaan, dalam bentuk stimulus - human organism - human - response (SHOHR). Kedua modalitas ini merupakan determinan perkembangan kognitif. Berdasarkan konsep tersebut, maka struktur kognitif tidak ditentukan oleh umur/tingkat perkembangan melainkan dapat berubah karena peran mediator tersebut (cognitive modifiability).

Dalam pembelajaran bahasa, teori skema dan peran lingkungan sosial ini dikembangkan menjadi teori transaksional (transactional theory) dalam proses membaca dan menulis. Seorang penulis berusaha mendapatkan suatu makna (meaning) melalui suatu transaksi dengan tulisan. Tulisan itu sendiri sebenarnya tidak punya makna; tulisan hanya memiliki potensi makna (potential of meaning). Makna akan diperoleh bila terjadi transaksi antara tulisan tersebut dengan isi skema (prior knowledge). Dalam proses menulisnya, penulis memilih simbol-simbol dan pola-pola bahasa untuk mewakili ide-ide yang hendak diungkapkannya. Simbol-simbol dan pola- 
pola bahasa itu baru bermakna bila digunakan untuk mewakili buah pikiran. Begitu pun makna dapat berbeda antara satu orang dengan orang lain tergantung pada skema orang yang bersangkutan. Itulah sebabnya sering terjadi interpretasi yang berbeda terhadap suatu hal yang sama.

Menulis juga suatu proses kreatif. Suatu proses kreatif dicirikan oleh kelancaran yaitu kemampuan untuk melahirkan banyak gagasan-gagasan baru. Fleksibilitas yaitu kemampuan untuk mengemukakan bermacam-macam pendekatan atau cara pemecahan masalah. Kemurnian (orisinalitas) pikiran yaitu kemampuan untuk mencetuskan gagasan dengan cara-cara yang asli dan tidak klise serta cenderung unik. Elaborasi yaitu kemampuan menguraikan sesuatu secara terinci, yakni merupakan aktivitas untuk merangkai sebuah ide atau jawaban-jawaban yang sederhana menjadi lebih detail. Redifinisi yaitu kemampuan untuk meninjau suatu persoalan berdasarkan perspektif yang berbeda dengan yang sudah diketahui oleh banyak orang.

Dengan menganggap kreativitas sebagai suatu proses, maka penentuan kriteria kreativitas juga dapat dilacak dari dimensi ini. Dengan menggunakan proses kreatif sebagai kriteria kreativitas, maka segala produk yang dihasilkan dari proses tersebut dianggap sebagai produk kreatif dan orangnya disebut sebagai orang kreatif. Teori investasi tentang kreativitas menyebutkan bahwa orang-orang kreatif 'beli murah jualnya mahal', maksudnya adalah, bahwa orang kreatif melakukan sesuatu yang tadinya dianggap aneh. Tapi bila kemudian terbukti berguna akan diikuti banyak orang. Adalah orang yang pertamakali mencoba sesuatu yang baru yang bisa disebut kreatif.

Proses kreatif dalam aktivitas menulis terjadi ketika berlangsung transaksi antara penulis dengan potensi makna yang dimiliki oleh tulisan. Kreativitas akan tercermin dari topik yang dipilih, cara mengembangkan alur (plot) tulisan, serta pemilihan kosakata dan pola-pola kalimat yang menunjukkan gaya (style) seorang penulis. Hasil transaksi tersebut merupakan sesuatu yang baru dan unik. Karena peran unsur kreativitas ini, setiap karya tulis tidak pernah ada yang persis sama satu sama lain. Keunikan suatu karya tulis mencerminkan kreativitas penulisnya. Dengan demikian, dapat dikatakan bahwa tulisan adalah refleksi dari pikiran kreatif, dan karena ia merupakan hasil transaksi maka ia sekaligus juga mengembangkan pikiran (menambah skema yang telah ada sebelumnya). 
Dengan demikian kegiatan menulis, khususnya menulis Bahasa Inggris, adalah suatu proses kognitif dan kreatif yang terjadi secara berulang-ulang tetapi tidak linier. Secara kognitif, di dalam pikiran terdapat suatu skema yang mengandung potensi makna. Potensi ini berkembang karena adanya stimulus dari luar dan akan terjadi suatu transaksi antara potensi itu dengan pengaruh luar tersebut. Transaksi yang terjadi selain ditentukan oleh kemampuan kognitif, juga dipengaruhi oleh tingkat kreativitas individu. Hasil transaksi tersebut tertuang dalam suatu bentuk karya tulis yang baru dan unik. Karya tulis mengandung sejumlah komponen, yaitu isi tulisan yang merupakan tuangan dari ide-ide pikiran, susunan/organisasi ide, penggunaan struktur kalimat, kosakata dan gaya, serta penggunaan mekanik.

Menulis proses (process writing) adalah suatu pendekatan dalam pengajaran menulis yang mencoba menstimulasikan proses yang dialami seorang penulis ketika menulis, ke dalam pembelajaran menulis. Menurut Omaggio Hadley (1996), pendekatan proses cocok untuk pebelajar lanjut (advanced) karena mereka perlu lebih banyak belajar bagaimana proses menulis tersebut terjadi. Dalam pendekatan proses, lebih banyak waktu diberikan untuk menghasilkan suatu karya tulis karena di dalam proses tersebut terjadi penghayatan terhadap proses itu sendiri serta kesempatan mengeksplorasi berbagai topik baru. Penuangan kognisi kedalam bentuk tulisan memerlukan suatu proses yang bertahap. Meskipun tahapan itu tidak selalu linier, namun terdapat ciri-ciri yang menunjukkan bahwa penulis melalui beberapa tahapan dalam merampungkan tulisannya. Dalam proses menulis terjadi beberapa subproses mulai dari pramenulis, menulis, mengkaji, membaca ulang, merevisi, mengedit, dan mempublikasikan. Secara garis besar, proses menulis dapat dibagi menjadi tiga tahap, yaitu: Prewriting, meliputi kegiatan diskusi singkat mengenai jenis tulisan yang akan dipelajari, pemodelan, analisis terhadap organisasi dan gaya dalam model tersebut, analisis tujuan penulis dan pembacanya, dan latihan tentang topik-topik yang relevan dan unsur-unsur organisasi maupun bahasa yang diperlukan. Composing, meliputi kegiatan menulis apa yang telah ditetapkan, dengan bekal beberapa petunjuk dan langkah yang harus dilalui. Di sini dapat dilakukan beberapa hal seperti terlebih dahulu membuat kerangka karangan (outline) atau membuat beberapa pertanyaan pemandu (guide questions). Fokus latihan adalah pada pengembangan ide-ide dan 
penyusunan/organisasinya. Revising, meliputi kegiatan perbaikan isi, organisasi, penggunaan kosakata dan gaya tulisan, serta perbaikan pada struktur kalimat. Pebelajar diberikan daftar cek sebagai pedoman melakukan perbaikan.

Kompetensi adalah kapasitas, keterampilan, atau kemampuan untuk melakukan sesuatu dengan benar dan secara efisien; atau suatu lingkup kemampuan seseorang atau suatu kelompok (Kamus Psikologi Oxford, 2000). Kompetensi adalah kecakapan yang tuntas yang ditunjukkan melalui kinerja dalam situasi atau kerja tertentu dan yang ditandai oleh keterkaitan dengan patokan (kriterion) tertentu. Selaras dengan itu, Savignon (1983) mengatakan bahwa kompetensi bersifat dinamis dan pada dasarnya bersifat context specific. Dengan demikian, kompetensi memiliki sifat-sifat: (1) merupakan suatu kecakapan tuntas atau hasil belajar tuntas, (2) diperoleh melalui suatu kinerja, dan (3) adanya patokan atau kriteria.

Dalam konteks pembelajaran menulis, suatu kompetensi yang dinyatakan dalam suatu tujuan pembelajaran dapat terbentuk dari sejumlah kemampuan. Kompetensi menulis dalam Bahasa Inggris, misalnya, dapat terbentuk dari kemampuan menggali ide-ide yang otentik dan menarik, menyusun ide-ide secara teratur, menggunakan katakata yang tepat untuk mewakili ide-ide tersebut, penggunaan struktur bahasa yang benar dalam kalimat, dan penggunaan mekanika sesuai dengan konvensi penulisan yang diakui.

KTSP adalah kurikulum berbasis kompetensi yang mensyaratkan dilakukannya asesmen otentik terhadap kemampuan menulis. Asesmen otentik adalah asesmen yang bersifat riil sesuai dengan hakikat kompetensi itu sendiri, yaitu pengembangan anak didik untuk memiliki life skills. Asesmen otentik untuk kompetensi menulis adalah pemantauan kinerja menulis sebagaimana layaknya seorang penulis ketika menuliskan ide-ide menjadi sebuah karya tulis. Mengingat kompetensi menulis terbentuk melalui suatu proses menulis. Jadi, asesmen otentik untuk kemampuan menulis yang otentik adalah asesmen kinerja proses dan produk.

Dalam pembelajaran bahasa asing, ditemukan suatu studi yang dilakukan di Amerika Serikat mengenai bagaimana cara orang mengases hasil belajar siswa. Penelitian ini dilakukan secara online terhadap 97 ketua jurusan bahasa asing. Hasil penelitian menunjukkan bahwa asesmen terhadap hasil belajar siswa 
mengkombinasikan antara asesmen kinerja dan asesmen tradisional. Hal ini mengindikasikan pentingnya guru dapat melakukan asesmen kinerja secara baik, minimal untuk melengkap pendekatan asesmen yang secara tradisional telah mereka lakukan.

Asesmen kinerja adalah berbagai macam tugas dan situasi dimana peserta tes diminta untuk mendemonstrasikan pemahaman dan pengaplikasian pengetahuan yang mendalam, serta keterampilan di dalam berbagai macam konteks. Jadi boleh dikatakan bahwa "Performance Assessment" adalah suatu penilaian yang meminta peserta tes untuk mendemonstrasikan dan mengaplikasikan pengetahuan ke dalam berbagai macam konteks sesuai dengan kriteria yang diinginkan.

Dalam laporan Gauglianone (2009), asesmen kinerja dihubungkan dengan kualitas guru dalam melakukan pembelajaran. Penelitian dilakukan pada guru-guru/dosen di kampus California State University dimana mereka diberikan pelatihan menggunakan asesmen kinerja dan menerapkannya dalam pembelajaran. Hasilnya adalah bahwa para guru tersebut ternyata belum memiliki pandangan yang tepat tentang asesmen kinerja dan bagaimana melakukannya dan hal ini memengaruhi praktik asesmen yang mereka lakukan di kelas.

Asesmen kinerja adalah suatu prosedur yang menggunakan berbagai bentuk tugastugas untuk memperoleh informasi tentang apa dan sejauhmana yang telah dilakukan dalam suatu program. Pemantauan didasarkan pada kinerja (performance) yang ditunjukkan dalam menyelesaikan suatu tugas atau permasalahan yang diberikan. Hasil yang diperoleh merupakan suatu hasil dari unjuk kerja tersebut. Asesmen kinerja adalah penelusuran produk dalam proses. Artinya, hasil-hasil kerja yang ditunjukkan dalam proses pelaksanaan program itu digunakan sebagai basis untuk dilakukan suatu pemantauan mengenai perkembangan dari satu pencapaian program tersebut.

Terdapat tiga komponen utama dalam asesmen kinerja, yaitu tugas kinerja (performance task), rubrik performansi (performance rubrics), dan cara penilaian (scoring guide). Tugas kinerja adalah suatu tugas yang berisi topik, standar tugas, deskripsi tugas, dan kondisi penyelesaian tugas. Rubrik performansi merupakan suatu rubrik yang berisi komponen-komponen suatu performansi ideal, dan deskriptor dari setiap komponen tersebut. Cara penilaian kinerja ada tiga, yaitu (1) holistic scoring, 
yaitu pemberian skor berdasarkan impresi penilai secara umum terhadap kualitas performansi; (2) analytic scoring, yaitu pemberian skor terhadap aspek-aspek yang berkontribusi terhadap suatu performansi; dan (3) primary traits scoring, yaitu pemberian skor berdasarkan beberapa unsur dominan dari suatu performansi. Contoh unjuk kerja siswa yang dapat diases dengan asesmen kinerja antara lain penyajian lisan (seperti keterampilan berbicara, berpidato, baca puisi, membaca nyaring, bercerita, pemecahan masalah dalam kelompok. partisipasi dalam diskusi. Menari, memainkan alat musik, olah raga, menggunakan alat lab, dan bermain.

Asesmen kinerja (Performance) otentik karena dalam asesmen kinerja siswa dituntut untuk mendemontrasikan inkuiri ilmiah mereka, melakukan penalaran dan keterampilan dalam menyelesaikan beberapa tugas menarik dan menantang dalam konteks kehidupan nyata (NSTA, 2002). Agar mendapatkan alat evaluasi yang valid tugas-tugas kinerja harus memiliki criteria berikut (Nur, 2001) (1) memusatkan pada elemen-elemen pengajaran yang penting . (2) sesuai dengan isi kurikulum yang diacu, (3) mengintegrasikan informasi, konsep, keterampilan, dan kebiasaan kerja, (4) melibatkan siswa, (5) mengaktifkan kemauan siswa untuk bekerja, (6) layak dan pantas untuk seluruh siswa, (7) ada keseimbangan antara kerja kelompok dan kerja individu (8) terstruktur dengan baik untuk memudahkan pemahaman, (9) memiliki proses dan produk yang otentik, (10) memasukkan penilaian diri, (11) memungkinkan umpan balik dari orang lain.

Dalam kaitannya dengan asesmen terhadap kinerja menulis, ternyata konsistensi penilaian antara penilai bervariasi. Penelitian yang dilaporkan oleh Ling Shi (2008) menunjukkan bahwa tidak terjadi konsistensi antara penilai yang guru orang Cina dengan guru orang penutur asli bahasa Inggris. Hal berarti bahwa sangat diperlukan adanya pedoman penilaian yang dipahami oleh semua guru sehingga dapat vmemberikan rating yang konsisten terhadap karangan siswa. Dalam asesmen kinerja digunakan rubric penilaian yang mengandung paling tidak criteria penilaian dan pedoman penskoran.

Asesmen kinerja menulis dalam Bahasa Inggris dikembangkan berupa tugas menulis (writing task) yang terdiri atas pertanyaan atau pernyataan (petunjuk) sebagai pedoman pebelajar dalam menulis. Tugas tersebut juga menetapkan dalam kondisi apa 
pebelajar menyelesaikan tugas tersebut. Pada pembelajaran menulis proses, kondisi tersebut antara lain mengandung pemberian kesempatan untuk melakukan revisi.

Setiap tugas menulis: (1) Menyebutkan genre yang ditulis, (2) Meliputi kemampuan berpikir, pemecahan masalah, dan proses pembuatan teks, (3) Menantang dan dapat dikerjakan oleh semua pebelajar, (4) Kesempatan yang sama bagi semua pebelajar untuk memberikan respon, (5) Menghasilkan bukan hanya tulisan yang baik dari segi teori, tetapi juga tulisan yang menarik, dan (6) Disukai oleh semua pebelajar.

Kriteria kompetensi menulis idealnya ditetapkan bersama-sama antara guru dengan siswa. Lebih bijaksana jika guru terlebih dahulu merancang criteria tersebut berdasarkan pertimbangan profesionalnya, selanjutnya dibahas bersama-sama dengan siswa. Dengan cara ini, terbentuk ownership (rasa memiliki) siswa terhadap proses dan hasil belajarnya. Dalam asesmen otentik untuk kemampuan menulis, sejumlah ceklis baik yang bersifat umum (untuk penilaian umum sebuah tulisan) maupun spesifik untuk aspek-aspek menulis secara sendiri-sendiri dapat digunakan untuk memantau proses menulis, dan rubric penilaian digunakan untuk memantau produk/hasil belajar menulis.

Asesmen otentik untuk menentukan tingkat pencapaian (grade) dalam menulis dapat dilakukan dengan menggunakan tiga jenis skala penilaian (Marhaeni, 2005): (1) holistic scoring, yaitu pemberian skor berdasarkan impresi penilai secara umum terhadap kualitas tulisan; (2) analytic scoring, yaitu pemberian skor terhadap sejumlah komponen yang berkontribusi terhadap suatu tulisan; seperti struktur kalimat, isi, dan organisasi tulisan; dan (3) primary traits scoring, yaitu pemberian skor berdasarkan beberapa sifat khusus dari tugas menulis yang diberikan. Misalnya, bila pebelajar menulis suatu argumentasi, maka penilaian dilakukan terhadap, antara lain berapa argumen yang digunakan dan sejauhmana argumen tersebut tepat pemakaiannya.

Mengenai aspek-aspek apa saja yang harus dinilai dari sebuah tulisan, Omaggio Hadley (1996) mengutip Gaudiani yang menyebutkan ada empat aspek yang menentukan kualitas suatu tulisan yaitu isi, organisasi, gaya bahasa, dan struktur kalimat dan kosakata. Selanjutnya Jacobs dkk. (1988) mengembangkan suatu ESL Composition Profile yang meliputi lima aspek, yaitu isi, organisasi, kosakata, penggunaan bahasa, dan mekanik. Hout (1990) yang melakukan meta analisis terhadap aspek-aspek tulisan 
apa saja yang ditekankan oleh para penilai mengatakan bahwa sebagian terbesar penilaian didasarkan atas isi dan organisasi, lalu struktur kalimat, dan mekanik.

Dari uraian di atas dapat disimpulkan ada lima dimensi penting yang dinilai dalam tulisan, yaitu isi, organisasi, struktur kalimat, kosakata/gaya, dan mekanik; dan aspek isi dan aspek organisasi dianggap paling penting. Dengan menetapkan beberapa aspek untuk dinilai, maka teknik penilaian yang cocok adalah penilaian analitik, karena dengan menggunakan teknik ini semua aspek penting tersebut mendapat perhatian dan proporsi yang jelas.

\section{Metode Pelaksanaan Pengabdian}

Untuk mencapai tujuan, P2M ini dirancang dengan alur berfikir dan rancangan pelaksanaan kegiatan sebagai berikut. Alur berfikirnya adalah, bahwa guru merupakan ujung tombak keberhasilan pelaksanaan pendidikan/pembelajaran sekolah; oleh karena itu, maka mutu guru harus merupakan prioritas utama. Dalam konteks pembelajaran menulis bahasa Inggris di SMA, sesuai dengan hasil analisis kebutuhan, guru-guru ini sangat memerlukan bantuan untuk bias melaksanakan penilaian kemampuan menulis secara baik dan taat asas. Namun, berbagai diklat dan bintek yang dilakukan belum sampai secara mendalam mempelajari bagaimana melakukan penilaian kinerja menulis yang baik itu. Demikian pula, waktu pelatihan yang singkat dan relative tidak berkelanjutan menyebabkan pengetahuan yang diperoleh belum sampai pada tahap implementasi di kelas. Konsep yang dipegang untuk melakukan P2M ini adalah perlu pelatihan yang berkelanjutan dan pembimbingan yang baik hingga tahap implementasi di kelas.

Berdasarkan alur berfikir di atas, maka kerangka pemecahan masalah yang sekaligus akan menjadi kerangka kerja kegiatan P2M ini adalah sebagai berikut. (a) Refleksi awal, (b) Penetapan focus dan target hasil P2M, (c) Pelaksanaan kegiatan, (d) Evaluasi dan refleksi hasil kegiatan, (e) Pelaporan.Pelaksanaan kegiatan ini dilakukan dengan metode workshop berkelanjutan dalam 3 (tiga) tahap, yaitu: (1) Pelatihan, (2) Implementasi, dan (3) Refleksi dan perencanaan tindak lanjut. Sesuai dengan yang telah diuraikan pada bagian Pendahuluan maupun bagian Analisis Situasi, maka khayalak sasaran strategis P2M ini adalah guru-guru bahasa Inggris SMA se Kecamatan Buleleng, yang teridentifikasi masih belum mampu secara baik dan taat asas dalam 
melakukan penilaian kemampuan menulis bahasa Inggris siswa serta para pengawas mata pelajaran Bahasa Inggris di SMA Kecamatajn Buleleng sebagai pihak yang secara langsung mengawasi kegiatan akademik guru. Guru Bahasa Inggris yang terlibat sebanyak 17 orang dan pengawas berjumlah 3 orang.

\section{Hasil dan Pembahasan}

Dalam diskusi ada beberapa isu yang diangkat. Isu-isu tersebut telah ditanggapi oleh nara sumber dengan baik dan dari diskusi tersebut dapat diambil kesimpulan bahwa bahasa juga masalah perasaan, namun tetap mengedepankan logika berfikir dan kelengkapan informasi. Untuk itu bobot antara penilaian bahasa dengan isi sebagai aspek dalam menulis minimal sama. Agar dalam pengimplementasian penilaian kinerja menulis siswa lebih objektif, maka instrument penilaian sangatlah perlu untuk disiapkan dan digunakan. Instrumen penilaian tersebut hendaknya berisi deskripsi tentang aspekaspek menulis yang perlu untuk dinilai, baik dalam proses menulis maupun produknya. Proses perlu untuk dinilai untuk bisa merekam jejak tulisan dan motivasi siswa dalam menulis, karena proses tersebut akan menunjukkan kekuatan siswa dalam menulis. Sehingga untuk proses dan produk diberikan pembobotan 20:40 tidak 50:50 karena dalam produk sudah ada penilain proses. Tetapi juga untuk wujud bentuk pembelajaran agar tidak terkesan membeli kucing dalam karung.

Pengimplementasian instrument dilaksanakan daritahapan pre-writing sampai pada menghasilkan produk dalam bentuk genre naratif. Dari pengimplementasian proses menulis tersebut bisa diketahui bahwa pengaplikasian pendekatan proses ini tidak dapat dilakukan hanya dalam satu sesi saja karena adanya proses menulis. Diperlukan minimal 3 sesi untuk bisa sampai pada produk. Ketika siswa telah menghasilkan karyanya, pada mulanya guru merasakan kerumitan dalam menggunakan instrument tersebut karena detail sekali. Namun dengan semakin banyaknya pengalaman yang dimiliki, penilaian pun bisa dirasakan lebih mudah dan memberikan keuntungan dipihak guru, seperti guru menjadi lebih objektif menilai tulisan siswa. Di sisi lain, siswa juga mendapatkan keuntungan, seperti menjadi lebih terbuka dan mandiri. Siswa bisa menilai sendiri tulisannya dan mengetahui apa yang menjadi kelemahan mereka dalam menulis. Namun, ada pula siswa yang memiliki input rendah sehingga kurang mampu 
menggunakan instrument penilaian diri dengan baik. Namun dengan kesabaran dan pendampingan dari guru, siswa tersebut bisa dituntun untuk menggunakan instrument tersebut.

Kegiatan refleksi dan perencanaan tindak lanjut ini berlangsung dengan mengundang kembali guru-guru dan pengawas. Pada kegiatan ini dilakukan refleksi dengan metode diskusi kelompok kecil dan diskusi kelas. Peserta dibagi mnenjadi 2 kelompok kecil guna menyampaikan hasil pengimplemetasian instrument penilain kinerja menulis siswa. Setelah selesai, perwakilan dari masing-masing kelompok menyampaikan hasil refleksinya dalam diskusi kelas. Dari hasil refleksi pada diskusi kelas dapat ditarik kesimpulan bahwa, instrument tersebut dapat membantu guru untuk lebih objektif untuk memberikan penilaian terhadap kemampuan menulis siswa; melatih siswa untuk bisa menjadi pebelajar mandiri, lebih teliti karena berpatokan pada instrument yang sangat rinci sehingga mereka mampu mengevaluasi dirinya sendiri; dan adanya pemantauan dalam proses menulis membantu siswa untuk menghasilkan karya yang lebih baik. Namun, disisi lain, pengimplementasian instrument ini juga memiliki kelemahan. Instrumen yang rinci (analitik) terkesan rumit untuk diimplementasikan oleh beberapa orang guru pada awalnya sehingga perlu waktu yang lebih banyak untuk melakukan penskoran. Karena instrument ini digunakan juga untuk menilai proses, maka jumlah pertemuan pun jadi bertambah sedangkan keterampilan berbahasa yang lain juga harus diajarkan, dan input siswa yang rendah juga mempengaruhi kesuksesan penimplementasian instrument. Jadi disarankan, dengan kondisi sekolah yang berbeda-beda, terutama dari input siswa, guru agar tetap termotivasi untuk berlatih mengimplementasikan instrument tersebut agar dapat mendorong siswa untuk berprestasi. Instrumen tersebut bisa menjadi jalan keluar untuk bisa melatih diri menjadi objektif, melatih siswa untuk sadar akan dikelemahan dan kelebihan yang dimilikinya dalam menulis, serta mampu menghargai sustu proses dari pada hanya sekadar hasil.

Adapun tindaklanjut dari kegiatan P2M ini adalah pengimplementasian instrument secara berkelanjutan oleh guru-guru peserta dengan pengawasan dari pengawas mata pelajaran Bahasa Inggris di SMA Kecamatan Buleleng. MGMP Bahasa Inggris SMA Kecanatan Buleleng pun telah menyetujui untuk melakukan pertemuan kelompok mata 
pelajaran untuk terus menyempurnakan inbstrumen penilaian sesuai dengan kebutuhan dilapangan. Bila dipandang perlu, MGMP akan mengundang kembali pakar asesmen dari Universitas Pendidikan Ganesha untuk memberikan pelatihan maupun pendampingan dalam pengimplementasian instrument penilaian kinerja nmenulis siswa SMA dimasa mendatang untuk peningkatan kualitas keterampilan menulis siswa pada khususnya. Kegiatan pengabdian kepada masyarakat ini memberi manfaat tidak hanya kepada peserta tetapi kepada siswa dan pelaksana pengabdian kepada masyarakat. Peserta mendapatkan banyak pengetahuan tambahan tentang pendekatan proses dalam menulis. Proses ini diawali dengan prewriting dimana dalam tahap ini siswa diperkenalkan jenis text yang akan mereka kembangkan dalam menulis nanti. Yang dapat dilakukan dalam prewriting ini adalah mengeksplore ide-ide yang dimiliki oleh siswa baik dengan pemberian brainstorming berupa guiged questions, gambar-gambar yang bisa membuka ide siswa, hasil diskusi tentang jenis-jenis teks dan pengembangannya yang dilakukan sebelum pemberian brainstorming dan lain-lain. Selanjutnya adalah tahap composing. Dalam tahap ini, siswa mengatur ide-ide yang telah mereka dapatkan dalam prewriting dan mengolah informasi itu untuk membuat suatu draf tulisan sesui dengan pola pengembangan tulisan yang telah ditetapkan dan topic yang dipilih. Fokus dalam tahap ini adalah pengembangan tulisan yang dilihat dari organisasinya, kalimat-kalimat pendukung, sistematika penulisan, tata bahasa kosakata dan juga tanda baca. Sehingga tahapan ini merupakan tahapan yang paling kompleks atau bisa juga dikatakan sebagai langkah utama dalam menghasilkan suatu karya tulis. Selanjutnya, langkah yang terakhir adalah revising. Dilangkah yang terakhir ini, yang pertama diperbaiki oleh siswa adalah organisasi tulisan mereka serta kekoherenan kalimat-kalimat pendukung dan sistematika penulisan, setelah itu baru melangkah pada tata bahasa, kosakata dan juga tanda baca. Revisi ini dapat dilakukan dengan peer evaluation, students-teacher conference, mengisi ceklist dan juga refleksi diri, sehingga dengan valuasi diri dapat diketahui kelemahan dan kelebihan tulisan tersebut. Setelah adanya evaluasi diri ini maka siswa akan memperbaiki tulisan mereka secara lengkap kemudian setelah itu baru dikumpulkan.

Oleh karena tahapan yang panjang ini maka sistem soial yang dibangun antara siswa dan pengajar hendaknya dijaga agar tetap baik. Pengajar harus dapat selalu memotivasi 
siswanya agar dapat membangkitkan kepercayaan diri mereka sehingga mereka dapat mengembangkan ide mereka sebaik-baiknya dengan menggali potensi yang mereka miliki tanpa ada perasaan takut mencoba-coba. Karena coba-coba disini sangat penting untuk menstimulasi pengembangan ide. Disamping itu pendekatan proses menganjurkan agar siswa mau mengekspresikan idenya dengan berbagai cara untuk produk yang baik. Pada akhirnya kemandirian dalam menulis bisa tercipta. Lebih lanjut lagi, pengajar hendaknya mencurahkan waktunya untuk membantu siswa, memberikan arahan serta saran maupun komentar-komentar yang membangun untuk perbaikan tulisan siswa. Selanjutnya, siswa merespon hasil evaluasi tersebut dengan memperbaiki tulisan mereka. Pada sesi terakhir yaitu pengoreksian, pengajar hendaknya menanggalkan subjektifitas dan lebih membangun objektifitas dengan mengacu pada criteria penilaian yang telah disepakati sebelumnya. Dalam proses awal membangun kesepakatan sistem penilaian sudah terkandung nilai demokratis. Nilai demokratis yang lainnya adalah pada saat siswa diberikan kesempatan untuk memilih pekerjaan terbaik mereka untuk dijadikan sebagai final project mereka.

Kesuksesan pembelajar dalam menghasilkan suatua karya juga tidak terlepas dari sistem pendukung yang ada. Tidak hanya kehadiran pengajar dan siswa di dalam kelas namun juga berbagai sarana pendukung seperti bahan ajar yang berupa buku-buku yang berisi teori menulis dan juga berbagai sample tulisan dengan berbagai pola pengembangannya. Dengan demikian siswa diharapakan memiliki wawasan luas dan dasar kuat tentang konsep awal menulis sebelum mereka menghasilkan suatu produk tulisan. Yang tidak kalah pentingnya untuk disiapkan adalah system penilaian yang disepakati antara pengajar dan siswa sehingga keadilan dapat dirasakan dan dapat mengurangi subjektifitas pengajar sebagai pemberi skor. Format evaluasi diri juga sangat penting untuk disiapkan dari awal agar tidak menghambat proses perbaikan pekerjaan siswa.

Dengan persiapan yang dilakukan dengan matang untuk mendukung kesiapan pengaplikasian model ini, maka diharapkan tujuan awal dari pelajaran itu sendiri dapat terpenuhi. Siswa akan mampu mengenal karakteristik tulisan yang baik, bagaimana mengembamngkannya sehingga produk yang mereka hasilkan akan menjadi memuaskan terutama bagi diri mereka sendiri dan juga untuk pengajar untuk 
mengetahui sejauh mana kesuksesan penerapan program yang terlah direncanakan. Yang paling penting dari penerapan model ini adalah dapat membantu siswa untuk mengubah budaya tertutup mereka menjadi lebih terbuka dengan melatih siswa terbiasa untuk memuji dan menghargai diri sendiri. Pembelajar diharapkan mampu meningkatkan kepercayaan diri dan menyadari bahwa ada hal yang bagus dalam diri mereka dalam menulis. Kesadaran akan keunikan tiap individu juga penting dimana tiap individu memiliki kelemahan dan kelebihan yang mempengaruhi proses menulis. Karena itulah siswa diharapakan untuk bisa menampilkan kelebihan yang mereka miliki dan belajar unruk memeprbaiki kelemahan mereka dengan evaluasi diri. Lebih lanjut lagi setiap pebelajar hendaknya menjadi pebelajar yang mandiri, tidak mengandalkan atau selalu tergantung pada terutama kehadiran pengajar maupun bantuan dari teman untuk menyelesaikan tulisan. Karena bagaimanapun juga tulisan tidak bisa diselesaikan hanya dalam sekali duduk. Perlu banyak waktu untuk menyelesaikan tulisan yang baik dan tentu juga suasana yang nyaman dan tidak berada di bawah tekananan. Oleh karena itu kemandirian merupakan satu modal yang sangatlah penting dalam menulis. Dan hal ini diharapakan dapat tercipta dari penerapan instrumen ini.

Bagi pelaksana pengabdian, hasil kegiatan ini memberikan manfaat pula bahwa instrument yang dikembangkan memiliki kelebihan dan kelemahannya. Kelemahan tersebut perlu dipertimbangkan untuk bisa digunakan untuk melakukan perbaikan dan modifikasi sehingga sesuai dengan target yang diharapkan. Pada kahirnya, hubungan kerjasama yang baik tetap perlu dipertahankan dan dikembangkan anatar sekolah dan lembaga pengabdian pada masyarakat Undiksha agar bisa selalu mendampingi untuk peningkatan kualitas pendidikan pada umumnya.

\section{Penutup}

Dari kegiatan pengabdian kepada masyarakat ini dapat disimpulkan bahwa peserta kegiatan telah memiliki kemampuan yang baik dalam menyelenggarakan penilaian terhadap kinerja menulis bahasa Inggris siswa walaupun pada kenyataannya, instrument yang diaplikasikan masih memiliki kelemahan-kelemahan. Secara umum instrument tersebut dapat membantu guru untuk lebih objektif untuk memberikan penilaian terhadap kemampuan menulis siswa; melatih siswa untuk bisa menjadi pebelajar mandiri, lebih teliti karena berpatokan pada instrument yang sangat rinci sehingga 
mereka mampu mengevaluasi dirinya sendiri; dan adanya pemantauan dalam proses menulis membantu siswa untuk menghasilkan karya yang lebih baik. Namun, disisi lain, pengimplementasian instrument ini juga memiliki kelemahan. Instrumen yang rinci (analitik) terkesan rumit untuk diimplementasikan oleh beberapa orang guru pada awalnya sehingga perlu waktu yang lebih banyak untuk melakukan penskoran. Karena instrument ini digunakan juga untuk menilai proses, maka jumlah pertemuan pun jadi bertambah sedangkan keterampilan berbahasa yang lain juga harus diajarkan, dan input siswa yang rendah juga mempengaruhi kesuksesan penimplementasian instrument. Instrumen tersebut bisa menjadi jalan keluar untuk bisa melatih diri menjadi objektif, melatih siswa untuk sadar akan dikelemahan dan kelebihan yang dimilikinya dalam menulis, serta mampu menghargai sustu proses dari pada hanya sekadar hasil.

Adapun tindaklanjut dari kegiatan P2M ini adalah pengimplementasian instrument secara berkelanjutan oleh guru-guru peserta dengan pengawasan dari pengawas mata pelajaran Bahasa Inggris di SMA Kecamatan Buleleng. MGMP Bahasa Inggris SMA Kecanatan Buleleng pun telah menyetujui untuk melakukan pertemuan kelompok mata pelajaran untuk terus menyempurnakan inbstrumen penilaian sesuai dengan kebutuhan dilapangan. Bila dipandang perlu, MGMP akan mengundang kembali pakar asesmen dari Universitas Pendidikan Ganesha untuk memberikan pelatihan maupun pendampingan dalam pengimplementasian instrument penilaian kinerja nmenulis siswa SMA dimasa mendatang untuk peningkatan kualitas keterampilan menulis siswa pada khususnya.

Dari hasil kegiatan ini pula ada beberapa saran yang diajukan. Bagi guru Bahasa Inggris peserta pelatihan, dengan kondisi sekolah yang berbeda-beda, terutama dari input siswa, guru agar tetap termotivasi untuk berlatih mengimplementasikan instrument tersebut agar dapat mendorong siswa untuk berprestasi dan terus meningkatkan profesionalisme guru melalui pelaksanaan penilaian yang baik dan taat asas. Bagi sekolah tempat guru tersebut bertugas, diharapkan untuk tetap meningkatkan efektivitas pelaksanaan pembelajaran bahasa Inggris melalui praktik asesmen yang baik. Bagi pelaksana P2M, agar mampu melakukan perbaikan sesuai hasil refleksi untuk peningkatan kualitas dan kuantitas kolaboratif kampus-sekolah. 


\section{DAFTAR PUSTAKA}

Rocato, Mary K. et al. (2006). 'Assessing Student Written Communication Skills: A Gateway Writing Proficiency Test for Aspiring Journalism Majors'. College Student Journal. Vol. 39, 2006.

Confrey, Jere. (1995). 'A Theory of Intellectual Development'. Journal For the Learning of Mathematics. Vol. 15,1 (Februari). 38-47.

Fasting, Rolf. B. (2009). 'National Assessment of Writing Proficiency Among Norwegian Students in Compulsory Schools'. Scandinavian Journal of Educational Research Vol. 53 Issue 6 December 2009 pp. 617-637

Gardner, R.C. (2001). Language Learning Motivation, the Student, the Teacher, and the Researcher. Available at http://publish.uwo.ca/ gardner/

Guaglianone, Curtis L. et al. (2009). 'Teaching performance Assessment: A Comparative Study of Implementation and Impacts Amongst California State University Campuses'. Issues in Teacher Education, Vol. 22 March 2009.

Huot, B. (1990). 'Literature of Direct Writing Assessment'. Review of Educational Research Vol. 60 No. 6 (237-307).

Ling Shi (2008). 'Native and Nonnative EFL Writing Teachers' Evaluation of Chinese Students' English Writing'. Journal of Educational Researcher. University of Columbia.

Marhaeni, AAIN dkk. (2009). Pengembangan perangkat Asesmen Kinerja berorientasi Budaya Bali pada pembelajaran menulis bahasa Inggris siswa SMA. (laporan penelitian tidak dipublikasikan)

Marhaeni, AAIN. (2007). Portfolio Assessment, Achievement Motivation, and English Writing Ability. Jurnal Pendidikan dan Pengajaran Vol. 40 No. 4 Oktober 2007 hal. 872-888.

Nitko, A.J. (1996). Educational Assessment of Students. $2^{\text {nd }}$ Edition. New Jersey: Merrill.

O’Donnel,T. \& Paiva, J.L. (1993). Independent Writing $2^{\text {nd }}$ Edition. Boston: Heinle\&Heinle Publishers.

Omaggio Hadley, A. (1993). Teaching Language in Context $2^{\text {nd }}$ Edition. Boston: Heinle\&Heinle Publishers.

O’Malley, J.M. \& Valdez Pierce, L. (1996). Authentic Assessment for English Language Learners. New York: Addison-Wesley Publishing Company. 
Popham, W.J. (1995). Classroom Assessment, What Teachers Need to Know. Boston: Allyn and Bacon.

Ricardo Osorio, Jose G. (2008). 'A Study of Foreign Language Learning Outcomes Assessment in U.S. Undergraduate Education'. Foreign Language Annals, v41 n4 p590-610 win 2008.

Salvia, J. \& Ysseldyke, J.E. (1996). Assessment. $6^{\text {th }}$ Edition. Boston: Houghton Mifflin Company.

Savignon, S.J. (1983). Communicative Competence: Theory and Classroom Practice. California: Addison-Wesley Publishing Company.

Solso, R.L., Maclin, M.K., \& Maclin, O.H. 2005. Cognitive Psychology. Boston: Allyn\&Bacon. 